\title{
Discussion: Gated communities: definitions, causes and consequences
}

Sonia Roitman $\mathrm{PhD}$

Formerly University College London, London, UK
Jonathan Scopes MSc, CEng, MICE, MIStructE, CMIOSH, FAPS

Civil engineer - special projects, Az'Zaha Services and Building Contractors LLC, Al-Khuwair, Sultanate of Oman

\section{Contribution by J. Scopes}

In the paper by Roitman (2010), there seemed to be very little review of historical communities, which while perhaps not formally 'gated' nevertheless may have functioned in similar ways: for example mining streets and villages, Cadbury's Bournville, Kowloon walled city, 'estates' in some towns, and even 'ghettos' immediately come to mind.

\section{Author's reply}

Segregation is a feature that can be found in most cities, nearly since their foundation. Individuals and groups locate in the urban space influenced by several factors, for example access to land, financial resources, individual interests, preferences and values, social class and status, to mention a few. Likewise, enclosure (and confinement) has also been a present feature in many cities, justified by arguments related to safety, political control and the need to establish clear boundaries and social belonging. Medieval walled cities are just one example of this. Industrial estates for particular groups have also been common in several cities since the eighteenth century. What seems to be new with current worldwide gated communities is (a) their development and impact on the urban landscape owing to their great expansion, (b) their visibility in the city and the use of security devices (previously they used to be in not-so-visible areas, and the use of security devices was more subtle), and finally (c) the process of enclosure and privatisation related to gated communities is closely connected to the withdrawal of the public sphere by many gated community residents, which leads to secession and the lack of interest in public issues and governance.

\section{REFERENCE}

Roitman S (2010) Gated communities: definitions, causes and consequences. Proceedings of the Institution of Civil Engineers, Urban Design and Planning 163(2): 31-38.

\section{WHAT DO YOU THINK?}

To discuss this paper, please email up to 500 words to the editor at journals@ice.org.uk. Your contribution will be forwarded to the author(s) for a reply and, if considered appropriate by the editorial panel, will be published as discussion in a future issue of the journal.

Proceedings journals rely entirely on contributions sent in by civil engineering professionals, academics and students. Papers should be 2000-5000 words long (briefing papers should be 1000-2000 words long), with adequate illustrations and references. You can submit your paper online via www.icevirtuallibrary.com/content/journals, where you will also find detailed author guidelines. 